\title{
Detection of Pancytopenia Associated with Clinical Manifestation and Their Final Diagnosis
}

\author{
Mohammad Arphan Azaad1, Yongping $\mathrm{Li}^{2}$, Qiurong Zhang', Haixia Wang² \\ ${ }^{1}$ Department of Clinical Medical College, Dali University, Dali, China \\ ${ }^{2}$ Department of Hematology, Affiliated Hospital, Dali University, Dali, China \\ Email: arphanazaad@hotmail.com, ${ }^{*}$ yongping_li@hotmail.com
}

Received 29 June 2015; accepted 21 July 2015; published 24 July 2015

Copyright (C) 2015 by authors and Scientific Research Publishing Inc.

This work is licensed under the Creative Commons Attribution International License (CC BY). http://creativecommons.org/licenses/by/4.0/

(c) (i) Open Access

\begin{abstract}
Background: Pancytopenia is a common hematological parameter detected in Hematology department. It is important to find out the etiology of pancytopenia for the better management of patient. Pancytopenia represents a wide range of age groups and most pancytopenia is purely of bone marrow dysfunction origin. However, other causes such as hypersplenism and SLE are also frequently encountered. Objectives: To differentiate various causes of pancytopenia, to evaluate the hematological parameters in pancytopenic cases, and to analyze clinical manifestations in cases of pancytopenia. Materials and Methods: There were 25 admitted cases of pancytopenia at Affiliated Hospital of Dali University between the calendar year 2013 and 2014. A detail study was done on the basis of age, gender, clinical features, typical laboratory investigations, bone marrow examination, and final diagnosis. Results and Conclusions: Among 25 cases studied, megaloblastic anemia was the common cause of pancytopenia and incidence of megaloblastic anemia was higher in males after 5th decade of life. Pancytopenic cases age was ranging from 15 to 80 years. Fatigue and dizziness were the most common clinical features presented.
\end{abstract}

\section{Keywords}

Pancytopenia, Causes, Clinical Features, Final Diagnosis

\section{Introduction}

Pancytopenia is an important hematological problem encountered in our day-to-day clinical practice. It is a de-

"Corresponding author.

How to cite this paper: Azaad, M.A., Li, Y.P., Zhang, Q.R. and Wang, H.X. (2015) Detection of Pancytopenia Associated with Clinical Manifestation and Their Final Diagnosis. Open Journal of Blood Diseases, 5, 17-30. 
crease in all three cellular elements of peripheral blood leading to anemia, leucopenia and thrombocytopenia. Pancytopenia usually presents with symptoms of bone marrow failure such as pallor, dyspnea, bleeding, bruising and increased tendency to infections. The incidence of various disorders causing pancytopenia varies according to geographical distribution and genetic mutations. It can result from either failure of production of hematopoietic progenitors in bone marrow, or malignant cell infiltration, or antibody-mediated bone marrow suppression, or ineffective hematopoiesis and dysplasia, or peripheral sequestration of blood cells in overactive reticuloendothelial system. The main causes of pancytopenia are aplastic anemia, hypersplenism, myelodyplastic syndrome, nutritional deficiencies leading to megaloblastic anemia, sub-leukemic (acute) leukemias, multiple myeloma, paroxysmal nocturnal hemoglobinuria and infections such as HIV, miliary tuberculosis, brucellosis, and leishmaniasis [1].

Pancytopenia is not a disease entity but a triad of findings that may result from various disease processes, primarily or secondarily involving the bone marrow. Bone marrow aspiration and biopsy evaluation along with good clinical correlation are of utmost importance to evaluate the causes of pancytopenia and plan further investigations [2]. Pancytopenia is a common hematological problem with an extensive differential diagnosis, and the optimal diagnostic approach to pancytopenia remains undefined. Pancytopenia is not a disease but a triad of findings that may result from a number of disease processes. These disorders may affect bone marrow either primarily or secondarily, resulting in the manifestation of pancytopenia [3]. Pancytopnia can result from damage to bone marrow evidenced by low reticulocyte count, or increased destruction of preformed blood cells peripherally with increased reticulocyte count [4].

Bone marrow examination is a simple and safe invasive procedure, which causes a moderate discomfort and can be performed easily. Its greatest utility is for investigating and it is an important diagnostic modality for evaluating the causes of pancytopenia [2]. In pancytopenia, the marrow can be hypocellular or hypercellular. The hypoplastic marrow, which occurs in $2 \%$ of pediatric ALL patients, may be misdiagnosed as aplastic anemia. Studies done have shown leukemia to be the second most common cause of pancytopenia in pediatric patients, marginally behind aplastic anemia [5].

\section{Methods and Materials}

A retrospective study of 25 admitted cases of pancytopenia in the calendar year 2013 and 2014 was done; study was divided on the basis of age of detection, presence of clinical features, hematological parameters and final diagnosis of pancytopenic cases. Pancytopenia due to the effect of chemotherapy and radiotherapy were excluded from this study.

Pancytopenia is defined by the presence of the following:

1) Hemoglobin (Hb.) level-below $135 \mathrm{~g} / \mathrm{L}$ for males and below $115 \mathrm{~g} / \mathrm{L}$ for females;

2) Total Leucocyte Count (TLC)-below $4 \times 10^{9} / \mathrm{L}$;

3) Platelet (Plt.) count-below $150 \times 10^{9} / \mathrm{L}[6]$.

\section{Results}

Out of 25 cases admitted as pancytopenia during these two years (2013 and 2014) 28\% were diagnosed as megaloblastic anemia, $20 \%$ were diagnosed as aplastic anemia, 16\% were diagnosed as MDS, $12 \%$ were diagnosed as AML, remaining 24\% consists of SLE, Non Hodgkin's lymphoma, hypersplenism, HIV infection and hemophagocytic Syndrome. $52 \%$ of diagnosed cases were male and rest $48 \%$ were female. $48 \%$ of diagnosed case were between age of 30 to 59 years, $44 \%$ of diagnosed case were between age above or equal to 60 years and $8 \%$ were between age of 15 to 29 years.

$80 \%$ of cases have clinical features of Anemia, $40 \%$ of cases have clinical features of thrombocytopenia; $36 \%$ of cases have clinical features of leucopenia. Reticulocyte counts were elevated in the case of SLE and hypersplenism. In hemophagocytic syndrome reticulocyte count was only $0.32 \%$.

Megaloblastic anemia tends to be in male patient usually after 5th to 6th decade of their life. Clearly, nutrition deficiency and absorption disorder seems to be associating factors. Similarly myelodysplastic syndrome was also predominantly seen in patient after sixth decades of their life. Since the prevalence of malaria, Kalazar is quiet low in China as compared to other countries as a result of which pancytopenia due to tropical origin was quite rare in our study. Among leukemia incidence of acute myeloid leukemia in particular acute promyelocytic 
leukemia was found to be a important cause of pancytopenia, which is similar to other studies as well. In some part of world hypersplenism, hypocellular marrow (predominantly aplastic anemia) was the leading cause.

\section{Summary of Admitted Case of Pancytopenia}

\begin{tabular}{|c|c|c|c|c|c|c|}
\hline $\begin{array}{l}\text { Case } \\
\text { Number }\end{array}$ & $\begin{array}{c}\text { Age } \\
\text { (in Years) }\end{array}$ & Gender & Diagnosis & WBC Profile & RBC Profile & $\begin{array}{l}\text { Platelets } \\
\text { Profile }\end{array}$ \\
\hline 1 & 43 & Male & $\begin{array}{c}\text { Acute } \\
\text { Promyelocytic } \\
\text { Leukemia }\end{array}$ & $\begin{array}{c}\text { WBC: } 0.96 \times 10^{9} / \mathrm{L} \\
\mathrm{N}(21.94 \%), \mathrm{L}(66.74 \%)\end{array}$ & $\begin{array}{c}\text { RBC: } 2.43 \times 10^{12} / \mathrm{L} \\
\text { Hb: } 79 \mathrm{~g} / \mathrm{L} \\
\text { MCV: } 91.81 \mathrm{fl} \\
\text { RET } \%: 0.04 \%\end{array}$ & $29 \times 10^{9} / \mathrm{L}$ \\
\hline 2 & 80 & Male & $\begin{array}{l}\text { Megaloblastic } \\
\text { Anemia }\end{array}$ & $\begin{array}{c}\text { WBC: } 2.74 \times 10^{9} / \mathrm{L} \\
\mathrm{N}(20.42 \%), \mathrm{L}(74.51 \%)\end{array}$ & $\begin{array}{c}\text { RBC: } 1.3 \times 10^{12} / \mathrm{L} \\
\text { Hb: } 57 \mathrm{~g} / \mathrm{L} \\
\text { MCV: } 123.8 \mathrm{fl} \\
\text { RET } \%: 0.77 \%\end{array}$ & $13 \times 10^{9} / \mathrm{L}$ \\
\hline 3 & 61 & Female & Hypersplenism & $\begin{array}{c}\text { WBC: } 2.32 \times 10^{9} / \mathrm{L} \\
\mathrm{N}(55.6 \%), \mathrm{L}(34.9 \%)\end{array}$ & $\begin{array}{c}\text { RBC: } 3.32 \times 10^{12} / \mathrm{L} \\
\text { Hb: } 96 \mathrm{~g} / \mathrm{L} \\
\text { MCV: } 93.1 \mathrm{fl} \\
\text { RET } \%: 3.41 \%\end{array}$ & $95 \times 10^{9} / \mathrm{L}$ \\
\hline 4 & 60 & Male & $\begin{array}{l}\text { Megaloblastic } \\
\text { Anemia }\end{array}$ & $\begin{array}{c}\text { WBC: } 3.04 \times 10^{9} / \mathrm{L} \\
\mathrm{N}(25.6 \%), \mathrm{L}(60.9 \%)\end{array}$ & $\begin{array}{c}\text { RBC: } 1.67 \times 10^{12} / \mathrm{L} \\
\text { Hb: } 72 \mathrm{~g} / \mathrm{L} \\
\text { MCV: } 131.7 \mathrm{fl} \\
\text { RET } \%: 0.68 \%\end{array}$ & $47 \times 10^{9} / \mathrm{L}$ \\
\hline 5 & 72 & Male & $\begin{array}{l}\text { Acute Myeloid } \\
\text { Leukemia }\end{array}$ & $\begin{array}{c}\text { WBC: } 2.85 \times 10^{9} / \mathrm{L} \\
\mathrm{N}(5.7 \%), \mathrm{L}(77.54 \%)\end{array}$ & $\begin{array}{c}\text { RBC: } 2.17 \times 10^{12} / \mathrm{L} \\
\text { Hb: } 82 \mathrm{~g} / \mathrm{L} \\
\text { MCV: } 114.7 \mathrm{fl} \\
\text { RET } \%: 0.68 \%\end{array}$ & $79 \times 10^{9} / \mathrm{L}$ \\
\hline 6 & 69 & Female & $\begin{array}{l}\text { Myelodysplastic } \\
\text { Syndrome }\end{array}$ & $\begin{array}{c}\text { WBC: } 1.37 \times 10^{9} / \mathrm{L} \\
\mathrm{N}(51.1 \%), \mathrm{L}(32.1 \%)\end{array}$ & $\begin{array}{c}\text { RBC: } 2.75 \times 10^{12} / \mathrm{L} \\
\text { Hb: } 96 \mathrm{~g} / \mathrm{L} \\
\text { MCV: } 106.9 \mathrm{fl} \\
\text { RET } \%: 2.49 \%\end{array}$ & $20 \times 10^{9} / \mathrm{L}$ \\
\hline 7 & 34 & Female & Aplastic Anemia & $\begin{array}{c}\text { WBC: } 1.51 \times 10^{9} / \mathrm{L} \\
\mathrm{N}(45.7 \%), \mathrm{L}(43.7 \%)\end{array}$ & $\begin{array}{c}\text { RBC: } 2.18 \times 10^{12} / \mathrm{L} \\
\text { Hb: } 73 \mathrm{~g} / \mathrm{L} \\
\text { MCV: } 96.8 \mathrm{fl} \\
\text { RET } \%: 1 \%\end{array}$ & $6 \times 10^{9} / \mathrm{L}$ \\
\hline 8 & 59 & Female & HIV/AIDS & $\begin{array}{l}\text { WBC: } 1.27 \times 10^{9} / \mathrm{L} \\
\text { N }(55.9 \%), L(26 \%)\end{array}$ & $\begin{array}{c}\text { RBC: } 2.64 \times 10^{12} / \mathrm{L} \\
\text { Hb: } 75 \mathrm{~g} / \mathrm{L} \\
\text { MCV: } 85.2 \mathrm{fl} \\
\text { RET } \%: 1.2 \%\end{array}$ & $33 \times 10^{9} / \mathrm{L}$ \\
\hline 9 & 59 & Female & $\begin{array}{l}\text { Megaloblastic } \\
\text { Anemia }\end{array}$ & $\begin{array}{c}\text { WBC: } 3.55 \times 10^{9} / \mathrm{L} \\
\mathrm{N}(55.54 \%), \mathrm{L}(37.54 \%)\end{array}$ & $\begin{array}{c}\text { RBC: } 1.7 \times 10^{12} / \mathrm{L} \\
\text { Hb: } 73 \mathrm{~g} / \mathrm{L} \\
\text { MCV: } 130.6 \mathrm{fl} \\
\text { RET } \%: 0.85 \%\end{array}$ & $46 \times 10^{9} / \mathrm{L}$ \\
\hline 10 & 62 & Female & $\begin{array}{l}\text { Myelodyspalstic } \\
\text { Syndrome }\end{array}$ & $\begin{array}{c}\text { WBC: } 1.81 \times 10^{9} / \mathrm{L} \\
\mathrm{N}(22.64 \%), \mathrm{L}(73.54 \%)\end{array}$ & $\begin{array}{c}\text { RBC: } 2.02 \times 10^{12} / \mathrm{L} \\
\text { Hb: } 68 \mathrm{~g} / \mathrm{L} \\
\text { MCV: } 105.9 \mathrm{fl} \\
\text { RET } \%: 0.62 \%\end{array}$ & $85 \times 10^{9} / \mathrm{L}$ \\
\hline 11 & 57 & Female & $\begin{array}{l}\text { Acute P } \\
\text { romyelocytic } \\
\text { Leukemia }\end{array}$ & $\begin{array}{c}\text { WBC: } 1.11 \times 10^{9} / \mathrm{L} \\
\mathrm{N}(5.42 \%), \mathrm{L}(91.91 \%)\end{array}$ & $\begin{array}{c}\text { RBC: } 2.12 \times 10^{12} / \mathrm{L} \\
\text { Hb: } 63 \mathrm{~g} / \mathrm{L} \\
\text { MCV: } 93.9 \mathrm{fl} \\
\text { RET } \%: 1.78 \%\end{array}$ & $78 \times 10^{9} / \mathrm{L}$ \\
\hline 12 & 58 & Male & Aplastic Anemia & $\begin{array}{c}\text { WBC: } 0.63 \times 10^{9} / \mathrm{L} \\
\mathrm{N}(23.84 \%), \mathrm{L}(74.64 \%)\end{array}$ & $\begin{array}{c}\text { RBC: } 1.74 \times 10^{12} / \mathrm{L} \\
\text { Hb: } 53 \mathrm{~g} / \mathrm{L} \\
\text { MCV: } 92 \mathrm{fl} \\
\text { RET } \%: 1.17 \%\end{array}$ & $20 \times 10^{9} / \mathrm{L}$ \\
\hline 13 & 46 & Male & $\begin{array}{l}\text { Megaloblastic } \\
\text { Anemia }\end{array}$ & $\begin{array}{l}\text { WBC: } 3.51 \times 10^{9} / \mathrm{L} \\
\mathrm{N}(50 \%), \mathrm{L}(40 \%)\end{array}$ & $\begin{array}{c}\text { RBC: } 2.12 \times 10^{12} / \mathrm{L} \\
\text { Hb: } 81 \mathrm{~g} / \mathrm{L} \\
\text { MCV: } 109.9 \mathrm{fl} \\
\text { RET } \%: 5.43\end{array}$ & $113 \times 10^{9} / \mathrm{L}$ \\
\hline
\end{tabular}




\section{Continued}

\begin{tabular}{|c|c|c|c|c|c|c|}
\hline 14 & 76 & Male & $\begin{array}{l}\text { Megaloblastic } \\
\text { Anemia }\end{array}$ & $\begin{array}{c}\text { WBC: } 2.83 \times 10^{9} / \mathrm{L} \\
\mathrm{N}(37.5 \%), \mathrm{L}(50.5 \%)\end{array}$ & $\begin{array}{c}\text { RBC: } 1.45 \times 10^{12} / \mathrm{L} \\
\text { Hb: } 64 \mathrm{~g} / \mathrm{L} \\
\text { MCV: } 125.5 \mathrm{fl} \\
\text { RET } \%: 3.94\end{array}$ & $77 \times 10^{9} / \mathrm{L}$ \\
\hline 15 & 65 & Male & $\begin{array}{l}\text { Myelodysplastic } \\
\text { Syndrome }\end{array}$ & $\begin{array}{c}\text { WBC: } 2.14 \times 10^{9} / \mathrm{L} \\
\mathrm{N}(49.5 \%), \mathrm{L}(48.6 \%)\end{array}$ & $\begin{array}{c}\text { RBC: } 1.5 \times 10^{12} / \mathrm{L} \\
\text { Hb: } 61 \mathrm{~g} / \mathrm{L} \\
\text { MCV: } 112 \mathrm{fl} \\
\text { RET } \%: 2.44\end{array}$ & $25 \times 10^{9} / \mathrm{L}$ \\
\hline 16 & 49 & Female & $\begin{array}{l}\text { Megaloblastic } \\
\text { Anemia }\end{array}$ & $\begin{array}{c}\text { WBC: } 1.71 \times 10^{9} / \mathrm{L} \\
\mathrm{N}(48.6 \%), \mathrm{L}(45.6 \%)\end{array}$ & $\begin{array}{c}\text { RBC: } 1.73 \times 10^{12} / \mathrm{L} \\
\text { Hb: } 60 \mathrm{~g} / \mathrm{L} \\
\text { MCV: } 105.8 \mathrm{fl} \\
\text { RET } \%: 0.78\end{array}$ & $52 \times 10^{9} / \mathrm{L}$ \\
\hline 17 & 34 & Female & Aplastic Anemia & $\begin{array}{c}\text { WBC: } 3.38 \times 10^{9} / \mathrm{L} \\
\mathrm{N}(42.9 \%), \mathrm{L}(49.7 \%)\end{array}$ & $\begin{array}{c}\text { RBC: } 2.87 \times 10^{12} / \mathrm{L} \\
\text { Hb: } 105 \mathrm{~g} / \mathrm{L} \\
\text { MCV: } 106.3 \mathrm{fl} \\
\text { RET } \%: 1.92\end{array}$ & $14 \times 10^{9} / \mathrm{L}$ \\
\hline 18 & 51 & Male & $\begin{array}{l}\text { Non Hodgkin's } \\
\text { Lymphoma }\end{array}$ & $\begin{array}{c}\text { WBC: } 2.1 \times 10^{9} / \mathrm{L} \\
\text { N }(40 \%), L(36.7 \%)\end{array}$ & $\begin{array}{c}\text { RBC: } 2.37 \times 10^{12} / \mathrm{L} \\
\text { Hb: } 76 \mathrm{~g} / \mathrm{L} \\
\text { MCV: } 91.6 \mathrm{fl} \\
\text { RET } \%: 1.44\end{array}$ & $38 \times 10^{9} / \mathrm{L}$ \\
\hline 19 & 51 & Female & $\begin{array}{l}\text { Hemophagocytic } \\
\text { Syndrome }\end{array}$ & $\begin{array}{c}\text { WBC: } 0.38 \times 10^{9} / \mathrm{L} \\
\mathrm{N}(0.04 \%), \mathrm{L}(44.74 \%)\end{array}$ & $\begin{array}{c}\text { RBC: } 2.57 \times 10^{12} / \mathrm{L} \\
\text { Hb: } 77 \mathrm{~g} / \mathrm{L} \\
\text { MCV: } 80.2 \mathrm{fl} \\
\text { RET } \%: 0.32\end{array}$ & $47 \times 10^{9} / \mathrm{L}$ \\
\hline 20 & 58 & Male & Aplastic Anemia & $\begin{array}{c}\text { WBC: } 0.48 \times 10^{9} / \mathrm{L} \\
\mathrm{N}(20.84 \%), \mathrm{L}(64.64 \%)\end{array}$ & $\begin{array}{c}\text { RBC: } 2.19 \times 10^{12} / \mathrm{L} \\
\text { Hb: } 64 \mathrm{~g} / \mathrm{L} \\
\text { MCV: } 90.9 \mathrm{fl} \\
\text { RET } \%: 0.45\end{array}$ & $75 \times 10^{9} / \mathrm{L}$ \\
\hline 21 & 71 & Male & $\begin{array}{l}\text { Myelodysplastic } \\
\text { Syndrome }\end{array}$ & $\begin{array}{c}\text { WBC: } 2.37 \times 10^{9} / \mathrm{L} \\
\mathrm{N}(45.24 \%), \mathrm{L}(42.24 \%)\end{array}$ & $\begin{array}{c}\text { RBC: } 1.92 \times 10^{12} / \mathrm{L} \\
\text { Hb: } 61 \mathrm{~g} / \mathrm{L} \\
\text { MCV: } 93.8 \mathrm{fl} \\
\text { RET } \%: 0.61\end{array}$ & $77 \times 10^{9} / \mathrm{L}$ \\
\hline 22 & 60 & Male & $\begin{array}{l}\text { Megaloblastic } \\
\text { Anemia }\end{array}$ & $\begin{array}{c}\text { WBC: } 1.65 \times 10^{9} / \mathrm{L} \\
\mathrm{N}(64.9 \%), \mathrm{L}(33.9 \%)\end{array}$ & $\begin{array}{c}\text { RBC: } 1.24 \times 10^{12} / \mathrm{L} \\
\text { Hb: } 59 \mathrm{~g} / \mathrm{L} \\
\text { MCV: } 136.3 \mathrm{fl} \\
\text { RET } \%: 0.68\end{array}$ & $35 \times 10^{9} / \mathrm{L}$ \\
\hline 23 & 24 & Male & $\begin{array}{l}\text { Non Hodgkin's } \\
\text { Lymphoma }\end{array}$ & $\begin{array}{c}\text { WBC: } 1.45 \times 10^{9} / \mathrm{L} \\
\mathrm{N}(49.6 \%), \mathrm{L}(33.8 \%)\end{array}$ & $\begin{array}{c}\text { RBC: } 2.85 \times 10^{12} / \mathrm{L} \\
\text { Hb: } 84 \mathrm{~g} / \mathrm{L} \\
\text { MCV: } 80.7 \mathrm{fl} \\
\text { RET } \%: 1.29\end{array}$ & $33 \times 10^{9} / \mathrm{L}$ \\
\hline 24 & 15 & Female & $\begin{array}{l}\text { Systemic Lupus } \\
\text { Erythematous }\end{array}$ & $\begin{array}{c}\text { WBC: } 1.38 \times 10^{9} / \mathrm{L} \\
\mathrm{N}(45.7 \%), \mathrm{L}(44.2 \%)\end{array}$ & $\begin{array}{c}\text { RBC: } 2.14 \times 10^{12} / \mathrm{L} \\
\text { Hb: } 67 \mathrm{~g} / \mathrm{L} \\
\text { MCV: } 93.5 \mathrm{fl} \\
\text { RET } \%: 4.51\end{array}$ & $30 \times 10^{9} / \mathrm{L}$ \\
\hline 25 & 60 & Female & Aplastic Anemia & $\begin{array}{c}\text { WBC: } 1.97 \times 10^{9} / \mathrm{L} \\
\mathrm{N}(20.3 \%), \mathrm{L}(70.6 \%)\end{array}$ & $\begin{array}{c}\text { RBC: } 2.63 \times 10^{12} / \mathrm{L} \\
\text { Hb: } 90 \mathrm{~g} / \mathrm{L} \\
\text { MCV: } 99.2 \mathrm{fl} \\
\text { RET } \%: 1.43\end{array}$ & $14 \times 10^{9} / \mathrm{L}$ \\
\hline
\end{tabular}

- Cases of pancytopenia was divided according to the age group into three groups which is listed in Table 1 and Figure 1.

- Cases of pancytopenia were further divided on the basis of Gender which is listed in Table 2 and Figure 2.

- Clinical Features associated with cases of pancytopenia are due to Anemia, Thrombocytopenia and Leukopenia which can be listed in Table 3 and Figure 3.

- Cases of pancytopenia on initial detection was divided according to their Final Diagnosis and was listed accordingly as mentioned in Table 4 and Figure 4. 
Table 1. Division of pancytopenia on the basis of age group.

\begin{tabular}{cc}
\hline Age Group (in Years) & Cases of Pancytopenia \\
\hline $15-29$ & 2 \\
$30-59$ & 12 \\
Above or equal to 60 & 11 \\
\hline
\end{tabular}

Table 2. Division of pancytopenia on the basis of gender.

\begin{tabular}{cc} 
Gender & Cases of Pancytopenia \\
\hline Male & 13 \\
Female & 12 \\
\hline
\end{tabular}

Table 3. Division of cases on the basis of clinical features.

\begin{tabular}{cc}
\hline Clinical Features & Present in Cases of Pancytopenia \\
\hline Dizziness, fatigue, generalized weakness & 20 \\
Bruises, petechia, ecchymoses or visible bleeding & 10 \\
Fever & 9 \\
\hline
\end{tabular}

Table 4. Division of cases according to their final diagnosis.

\begin{tabular}{cc}
\hline Final Diagnosis & Total Number of Cases \\
Megaloblastic anemia & 7 \\
Aplastic anemia & 5 \\
Myelodysplastic syndrome & 4 \\
AML & 3 \\
Non Hodgkin's lymphoma & 2 \\
SLE & 1 \\
HIV/AIDS & 1 \\
Hypersplenism & 1 \\
Hemophagocytic syndrome & 1 \\
\hline
\end{tabular}

- Comparisons was done between different Complete Blood Count parameters of etiology of cases of pancytopenia and listed in Table 5.

\section{Discussion}

Pancytopenia should be suspected on clinical grounds when a patient presents with unexplained anemia, prolonged fever and tendency to bleed. The present study concludes that detailed primary hematological investigations along with bone marrow examination in cytopenic patients is helpful for understanding disease process, to diagnose or to rule out the causes of pancytopenia. It is also useful in planning further investigations and management [9]. Pancytopenia is present in various Hematological, Autoimmune and Infective diseases as our data above suggested. If we compare our data with other data, our data resembles to the data of other Asian Country whereas our data and British data are vastly different.

- On the basis of research published by BMJ in the year 2013 following evidence were documented as the leading cause of pancytopenia as listed in Table 6.

- In the year 2014 research was published in Indian Journal which list the following etiology for the cases of pancytopenia as listed in Table 7. 
number of cases

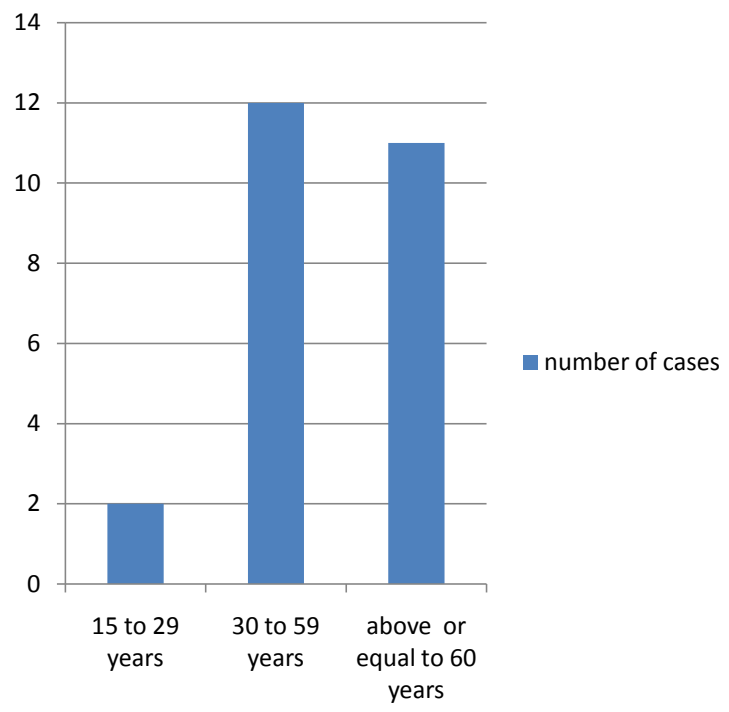

Figure 1. Division of pancytopenia on the basis of age group.

number of cases

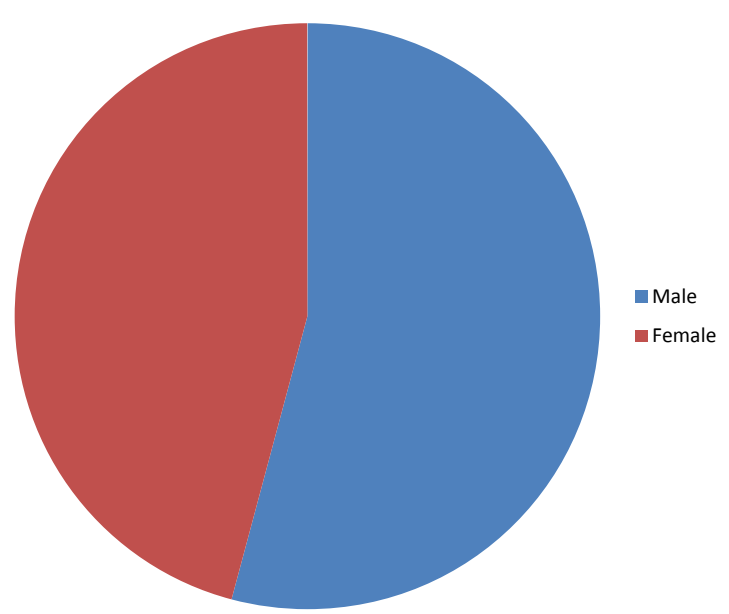

Figure 2. Division of pancytopenia on the basis of gender.

\section{Number Of Cases}

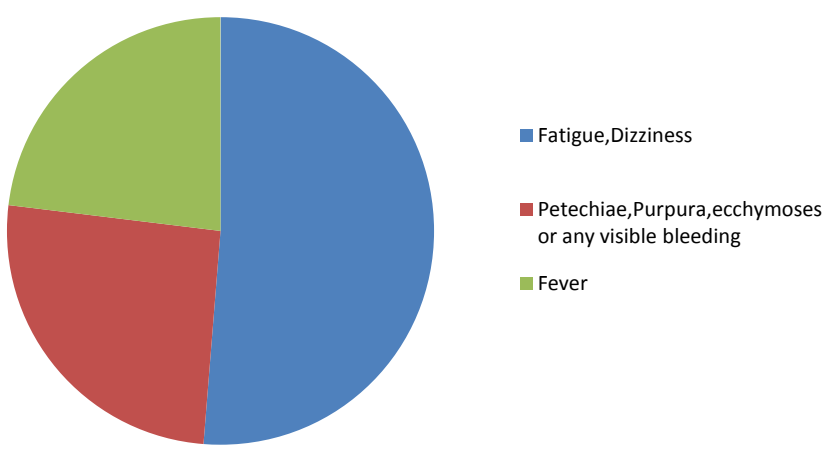

Figure 3. Division of cases on the basis of clinical features. 


\section{Cases}

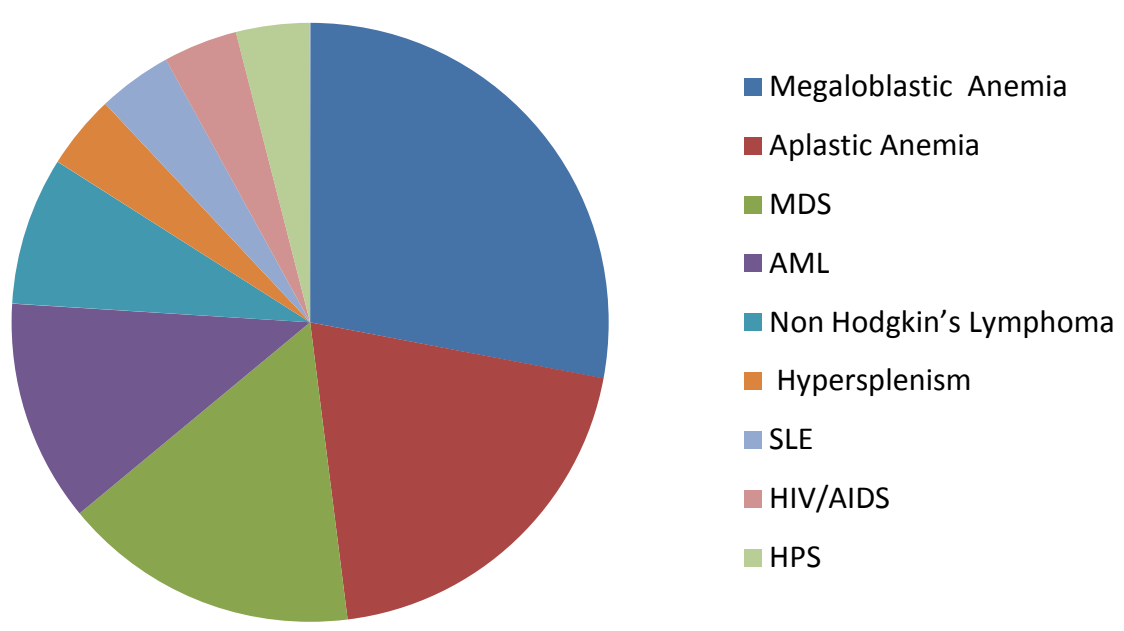

Figure 4. Division of cases according to their final diagnosis.

Table 5. Comparison of hematological parameters among leading causes of pancytopenia.

\begin{tabular}{|c|c|c|c|c|}
\hline Diagnosis & Megaloblastic Anemia & $\begin{array}{l}\text { Myelodysplastic } \\
\text { Syndrome }\end{array}$ & Aplastic Anemia & $\begin{array}{l}\text { Acute Myeloid } \\
\text { Leukemia }\end{array}$ \\
\hline Mean $\mathrm{Hb}$ & $66.57 \mathrm{~g} / \mathrm{L}$ & $71.5 \mathrm{~g} / \mathrm{L}$ & $77 \mathrm{~g} / \mathrm{L}$ & $74.6 \mathrm{~g} / \mathrm{L}$ \\
\hline Mean RBC & $1.60 \times 10^{12} / \mathrm{L}$ & $2.04 \times 10^{12} / \mathrm{L}$ & $2.32 \times 10^{12} / \mathrm{L}$ & $2.24 \times 10^{12} / \mathrm{L}$ \\
\hline $\begin{array}{c}\text { Mean } \\
\text { Reticulocyte in \% }\end{array}$ & $1.87 \%$ & $1.54 \%$ & $1.19 \%$ & $0.83 \%$ \\
\hline Mean PLT & $54.71 \times 10^{9} / \mathrm{L}$ & $51.75 \times 10^{9} / \mathrm{L}$ & $25.8 \times 10^{9} / \mathrm{L}$ & $62 \times 10^{9} / \mathrm{L}$ \\
\hline Mean WBC & $2.71 \times 10^{9} / \mathrm{L}$ & $1.92 \times 10^{9} / \mathrm{L}$ & $1.59 \times 10^{9} / \mathrm{L}$ & $1.64 \times 10^{9} / \mathrm{L}$ \\
\hline
\end{tabular}

- Following were the causes of pancytopenia as listed in Table 8 as the leading cause of pancytopenia according to research published on Journal of Pathology of Nepal in the year 2012.

- Among the Hematological Malignancies causing pancytopenia according to the research published on Journal of Pathology of Nepal on the year 2014 following evidence were documented as mentioned in Table 9.

- Comparison was done between common cause of pancytopenia on the basis of our study with common cause of pancytopenia according to research published on various Journal and following evidence were documented as listed in Table 10.

\section{Smears of Cases of Pancytopenia}

- Megaloblastic anemia: Bone marrow aspiration showed megaloblastic erythroid hyperplasia. Megaloblasts had the characteristic feature of sieved nuclear chromatin, asynchronous nuclear maturation and bluish cytoplasm with cytoplasmic blebs (Figure 5). Giant metamyelocytes and band forms were predominant in granulocyte series.

- Aplastic anemia: Bone marrow (BM) showed hypocellularity with suppression of erythropoiesis, myelopoiesis and megakaryopoiesis with relative lymphoplasmacytosis (Figure 6).

- AML: Bone marrow was hypercellular in all cases. Erythroid and megakaryocytic series were reduced. Majority of cells were myeloblasts and lymphoblasts, constituting more than $40 \%$ and $30 \%$ of cells in marrow, respectively. Bone marrow aspirate showed myeloblasts with Auer rods (Figure 7).

- Peripheral blood picture showed pancytopenia, and gametocytes of plasmodium falciparum were seen in blood smear in both cases (Figure 8). BM was hypercellular with megaloblastic change. No malarial parasites were seen on bone marrow smears. 
Table 6. Etiology on the basis of research of BMJ 2013 [6].

\begin{tabular}{|c|c|}
\hline Causes of Pancytopenia & Number of Cases \\
\hline \multicolumn{2}{|l|}{ Hypersplenism } \\
\hline Congestive splenomegaly & 45 \\
\hline Malaria & 15 \\
\hline Tropical splenomegaly & 3 \\
\hline Thalassemia & 1 \\
\hline Hodgkin's disease & 1 \\
\hline Idiopathic & 8 \\
\hline Total & $73(29.2 \%)$ \\
\hline \multicolumn{2}{|l|}{ Infections } \\
\hline AIDS & 30 \\
\hline Septicemia & 14 \\
\hline Enteric fever & 9 \\
\hline Tuberculosis & 8 \\
\hline Viral hepatitis & 3 \\
\hline Total & $64(25.6 \%)$ \\
\hline \multicolumn{2}{|l|}{ Myelosuppressants } \\
\hline Carcinoma & 18 \\
\hline Leukemia & 7 \\
\hline Non-Hodgkin's lymphoma (NHL) & 5 \\
\hline Hodgkin's disease & 2 \\
\hline Others & 10 \\
\hline Total & $42(16.8 \%)$ \\
\hline Megaloblastosis & $33(13.2 \%)$ \\
\hline Hypoplastic/aplastic anemia & $12(4.8 \%)$ \\
\hline Leukemia & $7(2.8 \%)$ \\
\hline Lymphoma & $2(0.8 \%)$ \\
\hline Plasma cell dyscrasia (PCD) & $2(0.8 \%)$ \\
\hline Myelodysplastic syndrome (MDS) & $1(0.4 \%)$ \\
\hline Miscellaneous & $14(5.6 \%)$ \\
\hline Grand total & $250(100 \%)$ \\
\hline
\end{tabular}

Table 7. Causes of pancytopenia on the basis of Indian Journal published on 2014 [7].

\begin{tabular}{ccc}
\hline Causes & Number of Cases & Percentage \\
\hline Megaloblastic anemia & 66 & 66 \\
Aplastic anemia & 18 & 18 \\
Malaria & 6 & 6 \\
Kalazar & 4 & 4 \\
Acute myeloid leukemia & 2 & 2 \\
Multiple myeloma & 2 & 2 \\
Myelodysplastic syndrome & 1 & 1 \\
Miliary tuberculosis & 1 & 1 \\
Total & 100 & $100 \%$ \\
\hline
\end{tabular}


Table 8. Causes of pancytopenia on the basis of Journal of Pathology of Nepal (2012) [8].

\begin{tabular}{cccc}
\hline Bone Marrow Findings & Male/Female & Number of cases & Percentage \% \\
\hline Hypoplastic bone marrow & $13 / 3$ & 16 & 29.6 \\
Hematological malignancies & $11 / 4$ & 15 & 27.78 \\
Megaloblastic anemia & $13 / 0$ & 13 & 24.1 \\
Erythroid hyperplasia & $1 / 5$ & 6 & 11.11 \\
Normocellular bone marrow & $1 / 3$ & 4 & 7.41 \\
Total & $39 / 15$ & 54 & $100 \%$ \\
\hline
\end{tabular}

Table 9. Hematological malignancies on the basis of Journal of Pathology of Nepal 2014 [8].

\begin{tabular}{ccc}
\hline Hematological malignancies & Number of cases & Percentage \% \\
\hline Acute myeloid leukemia & 7 & 46.7 \\
Myelodysplastic syndrome (MDS) & 4 & 26.6 \\
Acute lymphoblastic leukemia (ALL) & 2 & 13.3 \\
Non-Hodgkin lymphoma (NHL) & 1 & 6.7 \\
Chronic lymphoid leukemia (CLL) & 1 & 6.7 \\
Total & 15 & $100 \%$ \\
\hline
\end{tabular}

Table 10. Comparing most common cause of pancytopenia in percentage.

\begin{tabular}{cc}
\hline Research Center & Most Common Cause (\%) \\
\hline Affiliated Hospital of Dali University $(2013,2014)$ & Megaloblastic anemia (28\%) \\
On the basis of research of BMJ 2013 [6] & Hypersplenism (29.2\%) \\
On the basis of Indian Journal published on 2014 [7] & Megaloblastic anemia (66\%) \\
Journal of Pathology of Nepal (2012) [8] & Hypoplastic bone marrow (29.6\%) \\
\hline
\end{tabular}

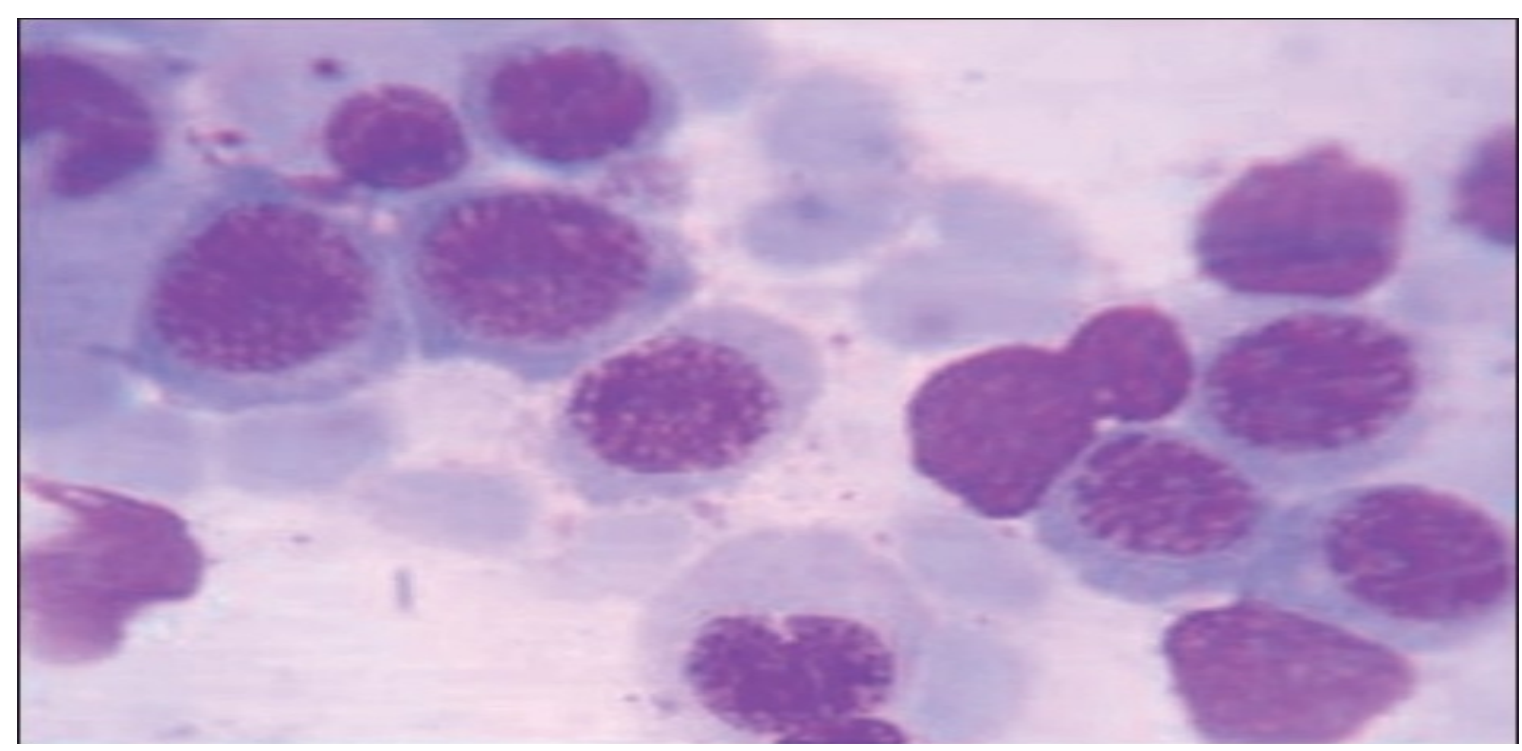

Figure 5. Bone marrow showing megaloblasts, with royal blue cytoplasm and sieve-like chromatin [9]. 


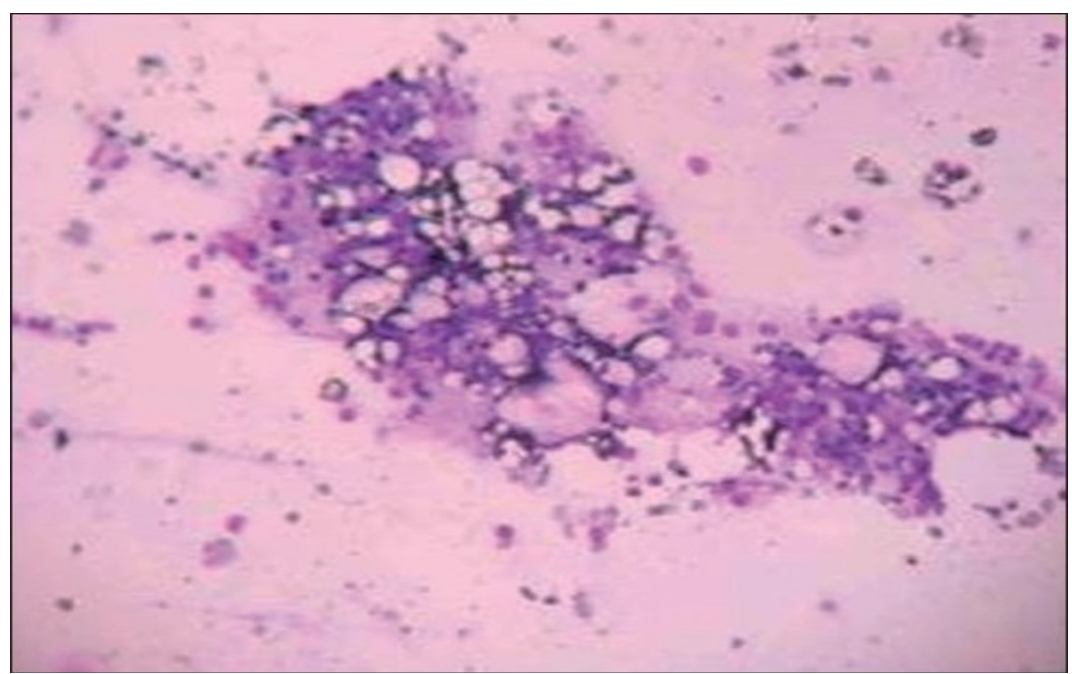

Figure 6. Bone marrow showing hypocellularity with increased fat and reactive lymphoplasmacytosis [9].

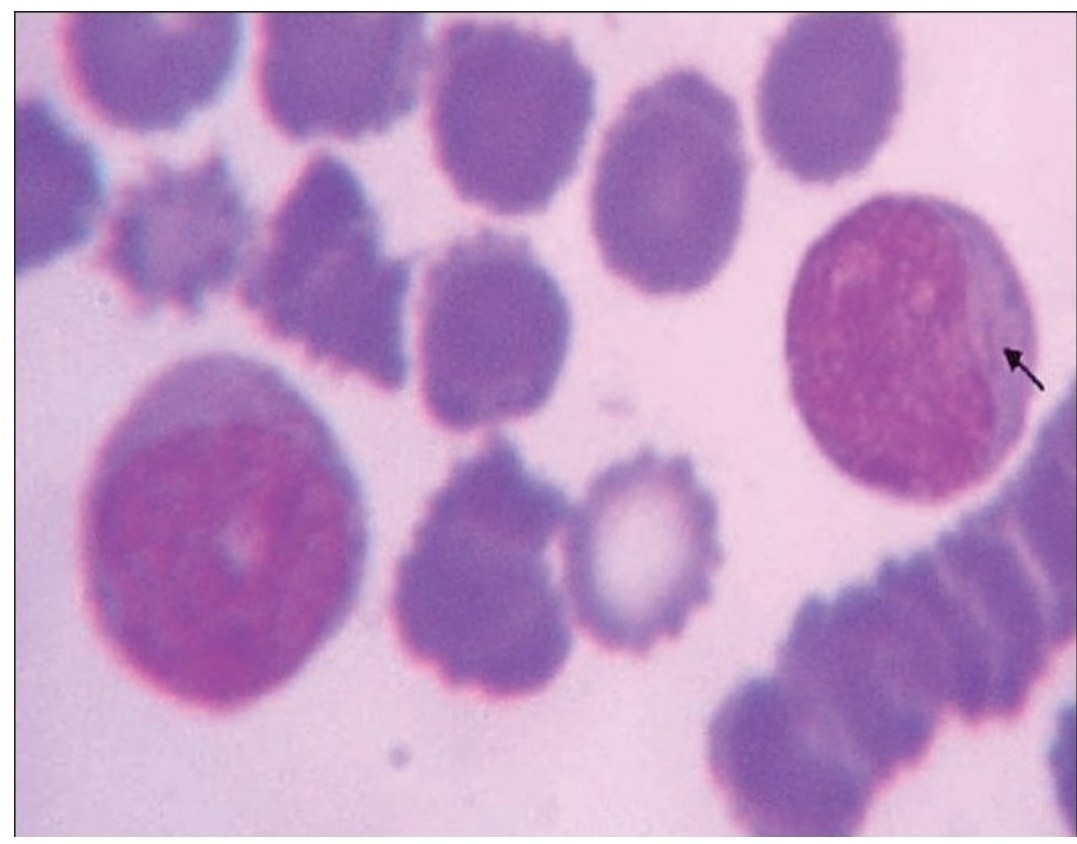

Figure 7. Bone marrow showing myeloblasts with Auer rod (arrow) [9].

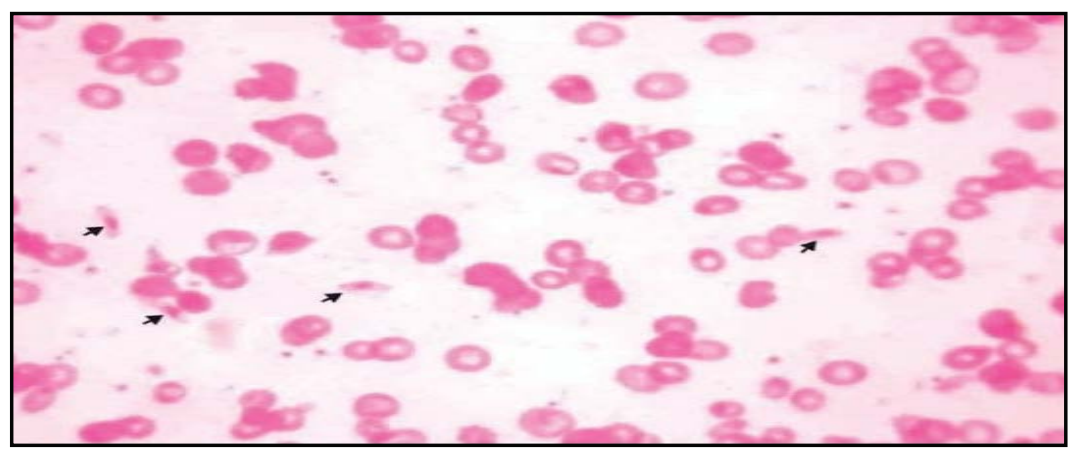

Figure 8. Pancytopenic smear showing gametocytes of plasmodium falciparum [9]. 


\section{Understanding about Common Cause of Pancytopenia}

* Megaloblastic anemia: Megaloblastic hematopoiesis is a hypercellular bone marrow failure syndrome intimately linked with abnormal cobalamin (B12) and folate metabolism or deficiency. These nutrients have a critical role in the synthesis of DNA. As a result, patients develop disordered blood cell proliferation, which subsequently can cause pancytopenia and altered immune function [10]. Megaloblastic anaemia was found to be predominant in various Indian studies because of high prevalence of nutritional anaemia in the Indian subcontinent. Most common complaints in their study and other Indian studies were fever followed by weakness and bleeding tendencies [2]. Vitamin $\mathrm{B}_{12}$ is essential for normal blood synthesis and neurological function. Vitamin $\mathrm{B}_{12}$ deficiency may cause megaloblastic anemia, subacute combined degeneration of the cord and psychiatric illness ("megaloblastic madness"). Notably, the degree of bone marrow suppression is typically inversely related to both the presence and severity of neurological involvement. As such, the coexistence of significant anemia and neurological deficits is thought to be rare [11].

* Aplastic anemia: Aplastic anemia is a potentially life-threatening failure of hemopoiesis characterized by pancytopenia and hypocellular bone marrow. Aplastic anemia is defined as pancytopenia with a hypocellular bone marrow in the absence of an abnormal infiltrate and with no increase in reticulin. Most cases are acquired and immune-mediated but there are also inherited forms. Environmental triggers include drugs, viruses and toxins but most cases are idiopathic. Aplastic anemia represents a well-recognized form of marrow failure. The bone marrow failure implies that peripheral blood cytopenia has arisen primarily as a result of a specific failure of bone marrow precursor cells to produce mature cells, rather than the production of abnormal cells that have a shorten survival or the production of normal cells that are subjected to an abnormal environment. There are two groups of bone marrow failure: the aplastic anemia, in which the failure lies in the pluripotent stem cell, and the single-cell cytopenia, in which the failure lies in one of the committed cell lines [12]. Aplastic anemia is a clonal disease of stem cell characterized by peripheral blood pancytopenia with hypocellular bone marrow. In most cases acquired aplastic anemia is an autoimmune, T-cell mediated disease (hematopoiesis is mediated by a population of $\mathrm{CD}^{+} \mathrm{T}$-cells which produce inhibitory cytokinesTNF-alpha, IFN-gamma, IL-6 which suppress hematopoiesis by affecting the mitotic cycle and cell killing by inducing apoptosis). In some cases, radiation, medical drugs and chemicals, viruses induce a depletion of hematopoietic stem cells by direct toxicity; immune diseases induce complex immune reactions leading to bone marrow failure [13].

- Classification of Aplastic Anemia on the basis of Severity is listed in Table 11.

* Myelodyspastic syndrome: The myelodysplastic syndromes (MDS) are among the commonest hematological malignant diseases, with an incidence of around 4 per 100,000 head of population per year and a prevalence of about 7 in 100,000. The incidence of MDS rises sharply with advancing age, reaching over 50 per 100,000 /year in the age group over 80 years. Median age at disease onset is around 70 years; only about $10 \%$ of patients are below the age of 50. The main symptoms are signs of hematopoietic insufficiency, particularly symptoms of anemia; less often, susceptibility to infection and signs of bleeding occur. The MDS are diseases of the hematopoietic stem cells. They are characterized by disturbances of differentiation and maturation, and by changes in the bone marrow stroma. These are accompanied not only by reducing blood cell counts, but also with an increased risk (about $20 \%$ to $25 \%$ ) of developing acute myeloid leukemia (AML). The disease course varies greatly from patient to patient, with median survival times ranging from a few months to many years [15].

* Acute Myeloid Leukemia: Acute myeloid leukemia (AML) is the most common acute leukemia in adults and the second most common frequent leukemia of childhood. Patients may present with lymphopenia or pancytopenia at diagnosis. Arginase II is expressed and released from AML blasts and is present at high concentrations in the plasma of patients with AML, resulting in suppression of T-cell proliferation. In addition, AML blasts can suppress the proliferation and differentiation of murine granulocyte-monocyte progenitors and human $\mathrm{CD} 34^{+}$progenitors [16].

* Hypersplenism: In hypersplenism there is peripheral pooling or trapping and destruction of cells in an enlarged spleen resulting in cytopenias. Increasing severity of the condition causes pancytopenia, as is seen in patients with chronic liver disease and thus hypersplenism may come out to be a common cause for pancytopenia. Causes of hypersplenism include congestive splenomegaly, malaria, tropical splenomegaly, thalassemia, Hodgkins disease or rarely idiopathic [6]. 
Table 11. Classification of aplastic anemia [14].

\begin{tabular}{cl}
\hline Classification & \multicolumn{1}{c}{ Criteria } \\
& BM cellularity $<25 \%$ (or $<50 \%$ if $<30 \%$ of BM is hematopoietic cells) \\
& And more than or equal to 2 of the following: \\
& $\checkmark$ Peripheral Blood Neutrophil Count $<0.5 \times 10^{9} / \mathrm{L}$ \\
Severe & $\checkmark$ Peripheral Blood Platelet Count $<20 \times 10^{9} / \mathrm{L}$ \\
& $\checkmark$ Peripheral Blood Reticulocyte Count $<20 \times 10^{9} / \mathrm{L}$ \\
Very severe & $\checkmark$ As above, but Peripheral Blood Neutrophil Count $<0.2 \times 10^{9} / \mathrm{L}$ \\
Non severe & Hypocellular BM with Peripheral Blood Values not meeting criteria for severe Aplastic Anemia \\
\hline
\end{tabular}

* HIV/AIDS: Haematological abnormalities are among the most common complications of human immune deficiency virus (HIV) infection. These involve all the lineages of blood cells. The mechanisms of these changes are multiple. It causes both quantitative and qualitative marrow defects. Immune cytopenias can occur directly due to HIV infection, whereas the effects of opportunistic infections, lymphomas, malignancy and anti-retroviral therapy (ART) also play an important role. Bone marrow abnormalities are common in HIV infection and increase in frequency with advancing disease. The consequences of these haematologic problems are twofold. First, they are associated with morbidity in themselves that can adversely alter the patient's quality of life, such as from anaemia (fatigue and dyspnoea), leucopenia (infections) and thrombocytopenia (bleeding). Second, they hinder treatment of the primary viral infection, secondary infections and by complicating neoplasm [17].

* Hemophagocytic syndrome: Hemophagocytic syndrome (HPS) is characterized by the proliferation of benign macrophages responsible for extensive phagocytosis of hematopoietic cells due to a hyperinflammatory reaction that may cause alteration in cytotoxic function of $\mathrm{T}$ lymphocytes and natural killer cells. One of the most consistent findings is low or absent cytotoxicity activity of natural killer (NK) cells. This biological event is related to a defective production of cytokines and anomalous inflammatory reaction that change the normal behavior of the immune system leading to deregulated cell signaling. Some studies suggest that the lack of perforins, a hydrophobic protein that is packaged into specialized cytotoxicity granules of human natural killer cells $\left(\mathrm{CD} 56^{\text {low }}, \mathrm{CD} 8^{-}\right)$, natural killer T cells $\left(\mathrm{CD} 56^{\text {low }}, \mathrm{CD}^{\text {+low }}\right)$, and activated $\mathrm{CD} 8^{+} \mathrm{T}$ helper 1 lymphocytes (Th1), results in insufficiency to regulate or terminate a immune response. These perforins seem to act with granzymes, a serine protease, leading to induced apoptosis in the target cells. Mutation in the perforin gene accounts for about $20 \%-40 \%$ of hemophagocytic lymphohistiocytosis subjects. HPS is a clinical pathological disease described by histiocytic proliferation, fever, hepatosplenomegaly, cytopenia, altered liver function, hyperferritinemia, hypertriglyceridemia, low plasma fibrinogen levels, and/or frequently coagulopathy disorders. It can be genetic, when associated with an inherited alteration of T lymphocytes and NK cells behavior, or acquired, associated with infection, mainly Epstein-Barr virus (EBV), autoimmune, or immunodeficiency status. It is rarely associated with B cell lymphoma [18].

* Non hodgkin lymphoma: NHL is known to infiltrate bone marrow more commonly than Hodgkin's disease and thus leading to pancytopenia [6].

* SLE: An increase in leucocyte apoptosis and impaired clearance of apoptotic cells has been observed in patients with systemic lupus erythematosus (SLE). Apoptotic cells are likely to be a key source of autoantigens in SLE as they express many of the nuclear autoantigens (in surface blebs and apoptotic bodies) that are relevant to this disease. The clearance of apoptotic cells is usually a rapid process, such that a few cells are usually seen in the extracellular environment in vivo. Apoptosis, an active process of programmed cell death, does not release intracellular components into the extracellular space, minimizing the risk of a damaging inflammatory response. Apoptotic cells express many of the nuclear autoantigens that are relevant to SLE in surface blebs and apoptotic bodies. Delayed apoptotic cell clearance leads to prolonged exposure of autoantigens and predisposes to autoantibody production. The demonstration of apoptotic bodies in vivo is unusual and supports the notion that the marrow may be a target organ in SLE. Autoantibodies may have a role in scavenging apoptotic cells and their abundance suggests that normal clearance mechanisms are defective or overwhelmed in such cases. This may provide a source of autoantigens, initiating an autoimmune response, complement activation, inflammation and tissue damage [19].

* Hyperthyroidism: Hyperthyroidism can be associated with various hematological disorders. Single lineage 
abnormalities such as anemia (34\%), leukopenia (5.8\%), thrombocytopenia (3.3\%) have been reported, but pancytopenia is a rare presentation. The suspected etiologic mechanisms include ineffective hematopoiesis, reduction in blood cell life span, and autoimmune process toxicity of thyroid hormone [20].

\section{Conclusions}

1) Megaloblastic anemia is the leading cause of pancytopenia;

2) Clinical features of anemia (fatigue, dizziness and generalized weakness) are predominant clinical features at the time of detection;

3) Mean age group of the patient at the time of detection of pancytopenia is approximately 55 years old (54.96 on calculation) with the youngest patient being 15 years old and the oldest being 80 years old;

4) Mean $\mathrm{Hb}$ and $\mathrm{RBC}$ are lowest among megaloblastic anemia patients and mean WBC and platelets are lowest among patients of aplastic anemia;

5) Incidence of pancytopenia is slightly higher in male populations.

\section{References}

[1] Hayat, A.S., Khan, A.H., Baloch, G.H. and Shaikh, N. (2014) Pancytopenia: Study for Clinical Features and Etiological Pattern of at Tertiary Care Settings in Abbottabad. The Professional Medical Journal, 21, 060-065.

[2] Desalphine, M., Bagga, P.K., Gupta, P.K. and Kataria, A.S. (2014) To Evaluate the Role of Bone Marrow Aspiration and Bone Marrow Biopsy in Pancytopenia. Journal of Clinical and Diagnostic Research, 8, FC11-FC15. http://dx.doi.org/10.7860/jcdr/2014/9042.5169

[3] Zeb Jan, A., Zahid, B., Ahmad, S. and Gul, Z. (2013) Pancytopenia in children: A 6-Year Spectrum of Patients Admitted to Pediatric Department of Rehman MedicalInstitute, Peshawar. Pakistan Journal of Medical Sciences, 29, 11531157.

[4] Al-Khalisi, K.A., Al-Zubaidy, A.S. and Rhaima, M. (2011) Pancytopenia Adult Patients at Baghdad Teaching Hospital. The Iraqi Postgraduate Medical Journal, 10, 441-448.

[5] Raja, S., Suman, F.R., Scott, J.X., Latha, M.S., Rajenderan, A. and Ethican, A. (2015) Pancytopenia: An Obstacle in the Diagnosis and Outcome of Pediatric Acute Lymphoblastic Leukemia. South Asian Journal of Cancer, 4, 68-71. http://dx.doi.org/10.4103/2278-330X.155648

[6] Jain, A. and Naniwadekar, M. (2013) An etiological Reappraisal of Pancytopenia-Largest Series Reported to Date from a Single Tertiary Care Teaching Hospital. BMC Hematology, 13, 10. http://dx.doi.org/10.1186/2052-1839-13-10

[7] Sweta, B., Chandoke, R.K. and Verma, A.K. (2014) A Prospective Clinico-Hematological Study in 100 Cases of Pancytopenia in Capital City of India. Journal of Applied Hematology, 5, 45-50.

[8] Lakhey, A., Talwar, O.P., Singh, V.K. and Shiva Raj, K.C. (2012) Clinico-Hematological Study of Pancytopenia. Journal of Pathology of Nepal, 2, 207-210. http://dx.doi.org/10.3126/jpn.v2i3.6023

[9] Gayathri, B.N. and Rao, K.S. (2011) Pancytopenia: A Clinico Hematological Study. Journal of Laboratory Physicians, 3, 15-20. http://dx.doi.org/10.4103/0974-2727.78555

[10] Trivette, E.T., Hoedebecke, K., Berry-Cabán, C.S. and Jacobs, B.R. (2013) Megaloblastic Hematopoiesis in a 20-YearOld Pregnant Female. American Journal of Case Reports, 14, 10-12. http://dx.doi.org/10.12659/AJCR.883734

[11] Rannelli, L., Watterson, R., Pandya, R. and Leung, A.A. (2014) Vitamin B12 Deficiency with Combined Hematological and Neuropsychiatric Derangements: A Case Report. Journal of Medical Case Reports, 8, 277.

[12] Biswajit, H., Pratim, P.P., Kumar, S.T., Shilpi, S., Krishna, G.B. and Aditi, A. (2012) Aplastic Anemia: A Common Hematological Abnormality among Peripheral Pancytopenia. North American Journal of Medical, 4, 384-388.

[13] Găman, A., Găman, G. and Bold, A. (2009) Acquired Aplastic Anemia: Correlation between Etiology, Pathophysiology, Bone Marrow Histology and Prognosis Factors. Romanian Journal of Morphology and Embryology, 50, 669-674.

[14] Guinan, E.C. (2011) Diagnosis and Management of Aplastic Anemia. The Education Program of the American Society of Hematology, 2011, 76-81. http://dx.doi.org/10.1182/asheducation-2011.1.76

[15] Germing, U., Kobbe, G.., Haas, R. and Gattermann, N. (2013) Myelodysplastic Syndromes: Diagnosis, Prognosis, and Treatment. Deutsches Äeblatt Inrztternational, 110, 783-790.

[16] Mussai, F., De Santo, C., Abu-Dayyeh, I., Booth, S., Quek, L., McEwen-Smith, R.M., Qureshi, A., Dazzi, F., Vyas, P. and Cerundolo, V. (2013) Acute Myeloid Leukemia Creates an Arginase-Dependent Immunosuppressive Microenvironment. Blood, 122, 749-758. http://dx.doi.org/10.1182/blood-2013-01-480129

[17] Kotwal, J., Singh, V., Kotwal, A., Dutta, V. and Nair, V. (2013) A Study of Haematological and Bone Marrow Changes 
in Symptomatic Patients with Human Immune Deficiency Virus Infection with Special Mention of Functional Iron Deficiency, Anaemia of Critically Ill and Haemophagocytic Lymphohistiocytosis. Medical Journal Armed Forces India, 69, 319-325.

http://dx.doi.org/10.1016/j.mjafi.2012.11.002

[18] de Mello, R.A., Fonseca, E., Brochado, M. and Quinaz, J.M. (2010) Hemophagocytic Syndrome Associated with Hodgkin's Lymphoma First Presenting as Fever and Pancytopenia. Case Reports in Medicine, 2010, Article ID: 759651. http://dx.doi.org/10.1155/2010/759651

[19] Hepburn, A.L., Lampert, I.A., Boyle, J.J., Horncastle, D., Ng, W.F., Layton, M., Vyse, T.J., Botto, M. and Mason J.C. (2007) In Vivo Evidence for Apoptosis in the Bone Marrow in Systemic Lupus Erythematosus. Annals of the Rheumatic Diseases, 66, 1106-1109. http://dx.doi.org/10.1136/ard.2006.065003

[20] Jha, P., Singh, Y.P., Ghimire, B. and Jha, B.K. (2014) Pancytopenia in a Surgical Patient, a Rare Presentation of Hyperthyroidism. BMC Surgery, 14, 108. http://dx.doi.org/10.1186/1471-2482-14-108 